\title{
Validation of in situ disappearance curves utilizing mathematical models for incubating fish meal and cottonseed meal
}

\author{
Validação de curvas de desaparecimento in situ utilizando modelos \\ matemáticos para incubação de farinha de peixe e farelo de algodão
}

\author{
Valiollah Palangi ${ }^{1 *}$; Maghsoud Besharati²
}

\section{Highlights:}

Appropriate diet formulating for ruminants requires detailed description of the nutritional value of feeds and their degradation kinetics in the rumen.

Meanwhile considering similar performance of the tested models, the biological characteristics of the models should be taken into account in order to implement the estimated parameters for practical use.

Non-linear models may help to obtain more accurate and plentiful descriptions about degradability of feeds. The optimization of models using MATLAB software has been done for the first time in this study and is novelty of the study.

\begin{abstract}
Four mathematical models were used to describe the ruminal disappearance of dry matter (DM) and crude protein (CP) of fish meal and cottonseed meal. Results of DM degradability particularity showed that all the models fitted well $\left(\mathrm{R}^{2}>0.95\right)$, however, considering that values below 0 or above 100 are not biologically justified in ruminal degradability, they are not acceptable. The models I and II were accepted to ruminal DM degradability of fish meal and cottonseed meal data. Only models I and II were successfully fitted to CP degradability of fish meal $\left(\mathrm{R}^{2}>0.96\right)$, and the I, II and III models were acceptable to ruminal $\mathrm{CP}$ degradability of cottonseed meal $\left(\mathrm{R}^{2}>0.98\right)$. In terms of effective degradability (ED) of DM and CP, model II generated higher values than other models. To appreciate fully the role of mathematical modelling in the biological sciences, it is necessary to consider the nature of feeds that evaluated and to review the types of models that may be constructed.
\end{abstract}

Key words: Fish meal. Cottonseed meal. In situ technique. Mathematical models.

Resumo

Quatro modelos matemáticos foram utilizados para descrever o desaparecimento ruminal da matéria seca (MS) e proteína bruta (PB) da farinha de peixe e farelo de algodão. Os resultados da particularidade da degradabilidade da MS mostraram que todos os modelos se ajustaram bem $\left(\mathrm{R}^{2}>0,95\right)$, no entanto, considerando que valores abaixo de 0 ou acima de 100 não são biologicamente justificados na degradabilidade ruminal, eles não são aceitáveis. Os modelos I e II foram aceitos para a degradabilidade ruminal da MS da farinha de peixe e e o farelo de algodão. Apenas os modelos I e II foram adaptados com sucesso à degradabilidade de $\mathrm{PB}$ da farinha de peixe $\left(\mathrm{R}^{2}>0,96\right)$, e os modelos I, II e III foram

\footnotetext{
${ }^{1}$ Department of Animal Science, Agricultural Faculty, Ataturk University, 25240, Erzurum, Turkey. E-mail: valiollah.palangi12@ ogr.atauni.edu.tr

2 University of Tabriz, Ahar Faculty of Agriculture and Natural Resources, Department of Animal Science, 51666, Tabriz, Iran. E-mail: m_besharati@hotmail.com

* Author for correspondence
} 
aceitáveis para a degradabilidade ruminal da $\mathrm{PB}$ do farelo de algodão $\left(\mathrm{R}^{2}>0,98\right)$. Em termos de degradabilidade efetiva (DE) da MS e da PB, o modelo II gerou valores mais altos que os demais. Para apreciar plenamente o papel da modelagem matemática nas ciências biológicas, é necessário considerar a natureza dos alimentos que foram avaliados e revisar os tipos de modelos que podem ser construídos.

Palavras-chave: Farinha de peixe. Farelo de algodão. Técnica in situ. Modelos matemáticos.

\section{Introduction}

Changes in digestive processes are of nutritional importance, because it determines the amount of nutrients consumed by the animal (Van Soest, 2018; Sauvant \& Noziere, 2016). Dynamic digestion models not only predict the nutritional value of feeds, dietary changes, microbial populations, and livestock physiological conditions, can also be detected the limiting factors of digestion process (Gregorini, Provenza, Villalba, Beukes, \& Forbes, 2018; Bannink, van Lingen, Ellis, France, \& Dijkstra, 2016; Reed, Arhonditsis, France, \& Kebreab, 2016). Various models have been proposed to describe the digestion and passage of feed in the digestive system of ruminants (Rochen et al., 2020; Palangi \& Macit, 2019; Dijkstra, Bannink, Bosma, Lantinga, \& Reijs, 2018). The amount of digestion is a function of the time it stops in the digestive tract (Oberson, Probst, \& Schlegel, 2019; Lopes et al., 2018). Changes in digestion can be described by dividing feed into fast-digesting, slow-digesting, and indigestible parts (Yousefian, Teimouri Yansari, \& Chashnidel, 2019; Vaga \& Huhtanen, 2018; Jin et al., 2017). Digestive models due to their dependence on the nature of the feedstuffs, were contained sequential equations that includes a linear and curved distribution of differential or integral equations that must be used to indicate the type of digestion process (Chanzanagh, Seifdavati, Gheshlagh, Abdibenemar, \& Seyedsharifi, 2019; Bannink et al., 2016; Reed et al., 2016).

The use of different models to estimate nutrient degradability parameters and formulating hypotheses about the biological principles governing the separation of ruminal digestion, leads to the development of mathematical models, that have ability to describing the disappearance of the rumen. Using these models ruminal digestion of feed can be estimated and different nutritional systems can be compared (Hanigan \& Daley, 2019; Lapierre, Larsen, Sauvant, Van Amburgh, \& Van Duinkerken, 2018).

The objective of this study was to determine ruminal disappearances of fish meal and cottonseed meal in the rumen by in situ and to estimate their degradability parameters using different mathematical models fitted by MATLAB and to identify the best model fitting the data.

\section{Materials and Methods}

\section{Mathematical modeling with MATLAB}

The models, I and II, are Simple negative exponential curve models (monomolecular, Mitscherlich, or first-order kinetics model) without and with a lag phase (Ørskov \& McDonald, 1979). Model III is Gompertz curve, asymmetrical about an inflection point $\mathrm{M}$, which can be calculated from $\mathrm{K}=\exp (\mathrm{cM})$ (France et al., 1990). Model IV is Generalised Mitscherlich, generalization of the model I (results in the model I for $\mathrm{d}=0$ ), with the addition of a square root time dependence component (Dhanoa, France, Siddons, Lopez, \& Buchanan, 1995). The models that we used included:

First-order kinetics model without lag phase

$$
\mathrm{P}=\mathrm{a}+\mathrm{b}\left(1-\mathrm{e}^{-\mathrm{ct}}\right)
$$

First-order kinetics model with lag phase

$$
\mathrm{P}=\mathrm{a}+\mathrm{b}\left(1-\mathrm{e}^{-\mathrm{c}(\mathrm{t}+\mathrm{L})}\right)
$$

Gompertz model

$$
\mathrm{P}=\mathrm{a}+\mathrm{b}\left(\mathrm{K}-\mathrm{K}^{\exp (-\mathrm{ct}) / \mathrm{K}-1)}\right.
$$


Generalised Mitscherlich model

$$
\mathrm{P}=\mathrm{a}+\mathrm{b}\left(1-\mathrm{e}^{-\mathrm{c}(\mathrm{t}-\mathrm{L})-\mathrm{d}(\mathrm{V} t-\sqrt{\mathrm{L}})}\right)
$$

Nowadays, optimization methods are widely used in various sciences (Milani, Çavdar, \& Aghjehkand, 2012; Çavdar, Mohammad, \& Milani, 2013), an optimization method combining MATLAB curve fitting toolbox and the numerical algorithm based on the Levenberg-Marquardt method was used. The models were identified through the editor toolstript, and the starting points and ranges required for the models were defined. We used a goodness of fit measure function to measure the error values of the fit curves in studied models.

\section{Effective degradability}

Effective degradability (ED) was calculated according to (Ørskov, Hovel, \& Mould, 1980) equation:

$$
\mathrm{ED}=\mathrm{a}+[\mathrm{bc} /(\mathrm{c}+\mathrm{k})]
$$

where 'a', 'b' and 'c' are the constants as described earlier in the different mathematical models above and ' $\mathrm{k}$ ' is the rumen fractional outflow rate $(0.02 / \mathrm{h}$, $0.03 / \mathrm{h}, 0.04 / \mathrm{h}, 0.05 / \mathrm{h}$ or $0.06 / \mathrm{h}$ ).

\section{Results}

\section{Statistical models output}

The results of the different models on the DM and CP degradability of fish meal and cottonseed meal were presented in Table 1 and 2. The comparison of various fitted models for DM degradability of fish meal and cottonseed meal, based on the coefficient of determination $\left(\mathrm{R}^{2}\right)$ and Adjusted $\left(\mathrm{R}^{2}\right)$ showed that models I and II was the best model. It may be concluded that the model with lag time (Model III) was the best model for description of degradability trends in CP of the cottonseed meal, because it was showed higher $\mathrm{r}^{2}$ and Adjusted $\mathrm{r}^{2}$.

Table1

Estimated DM degradability parameters of fish meal and cottonseed meal using different mathematical models

\begin{tabular}{|c|c|c|c|c|c|c|c|c|c|c|}
\hline & \multicolumn{6}{|c|}{ Prameter $^{1}$} & \multirow{2}{*}{$\mathrm{SSE}^{2}$} & \multirow{2}{*}{ R-Square } & \multirow{2}{*}{$\begin{array}{c}\text { Adj } \\
\text { R-Square }\end{array}$} & \multirow{2}{*}{ Iter } \\
\hline & $\mathrm{a}$ & $\mathrm{b}$ & $\mathrm{c}$ & $\mathrm{L}$ & d & $\mathrm{k}$ & & & & \\
\hline \multicolumn{11}{|l|}{ Fish meal } \\
\hline Model I ${ }^{3}$ & 6.51 & 22.69 & 0.0627 & - & - & - & 13.673 & 0.9600 & 0.9400 & 22 \\
\hline Model II & 7.10 & 22.10 & 0.0627 & 0.2636 & - & - & 13.673 & 0.9600 & 0.9200 & 6 \\
\hline Model III & -134.5 & 22.48 & 0.0669 & - & - & 0.8445 & 13.786 & 0.9597 & 0.9194 & 109 \\
\hline Model IV & 21.19 & 54.12 & 0.0075 & 210.3 & -0.0748 & - & 14.135 & 0.9587 & 0.8760 & 92 \\
\hline \multicolumn{11}{|c|}{ Cottonseed meal } \\
\hline Model I & 15.50 & 42.96 & 0.0219 & - & - & - & 11.947 & 0.9779 & 0.9668 & 22 \\
\hline Model II & 21.73 & 36.73 & 0.0219 & 0.1566 & - & - & 11.947 & 0.9779 & 0.9557 & 12 \\
\hline Model III & -35.41 & 36.50 & 0.0359 & - & - & 0.4785 & 10.827 & 0.9799 & 0.9599 & 109 \\
\hline Model IV & 136.30 & 197.60 & 0.0015 & 277.6 & -0.0055 & - & 21.028 & 0.9610 & 0.8831 & 92 \\
\hline
\end{tabular}
with MATLAB

${ }^{1} a=$ rapidly soluble fraction $(\%) ; b=$ slowly degradable fraction $(\%) ; c=$ degradation rate constant $(\% / \mathrm{h})$ of fraction ' $\mathrm{b}$ '; $L=$ lag time (h); $d=$ is the parameter pertaining to the variable fractional rate of degradation; $k=$ slope, or degradation rate coefficient $\left(\mathrm{h}^{-1}\right)$; ${ }^{2} \mathrm{SSE}=$ Sum of Squares Due to Error; R-Square= the square of the correlation between the response values and the predicted response values; Adj R-Square= Degrees of Freedom Adjusted R-Square; Iter = iteration number of MATLAB.

${ }^{3}$ Model I, First-order kinetics model without lag phase; Model II, First-order kinetics model with lag phase; Model III, Gompertz model; Model IV, Generalised Mitscherlich model. 
Table2

Estimated CP degradability parameters of fish meal and cottonseed meal using different mathematical models with MATLAB

\begin{tabular}{|c|c|c|c|c|c|c|c|c|c|c|}
\hline & \multicolumn{6}{|c|}{ Prameter $^{1}$} & \multirow{2}{*}{$\mathrm{SSE}^{2}$} & \multirow{2}{*}{$\begin{array}{c}\mathrm{R}- \\
\text { Square }\end{array}$} & \multirow{2}{*}{$\begin{array}{c}\text { Adj } \\
\text { R-Square }\end{array}$} & \multirow{2}{*}{ Iter } \\
\hline & $\mathrm{a}$ & $\mathrm{b}$ & $\mathrm{c}$ & $\mathrm{L}$ & d & $\mathrm{k}$ & & & & \\
\hline \multicolumn{11}{|l|}{ Fish meal } \\
\hline Model I ${ }^{3}$ & 6.74 & 25.78 & 0.0611 & - & - & - & 14.363 & 0.9669 & 0.9503 & 17 \\
\hline Model II & 8.76 & 23.76 & 0.0611 & 0.0816 & - & - & 14.363 & 0.9669 & 0.9337 & 5 \\
\hline Model III & -101.7 & 25.39 & 0.0672 & - & - & 0.7776 & 14.944 & 0.9655 & 0.9310 & 109 \\
\hline Model IV & -204.5 & 249 & -0.114 & 87.09 & -0.0167 & - & 9.824 & 0.9773 & 0.9320 & 92 \\
\hline \multicolumn{11}{|c|}{ Cottonseed meal } \\
\hline Model I & 14.18 & 42.74 & 0.0298 & - & - & - & 13.657 & 0.9813 & 0.9719 & 17 \\
\hline Model II & 20.95 & 35.97 & 0.0298 & 0.1725 & - & - & 13.657 & 0.9813 & 0.9626 & 11 \\
\hline Model III & 8.62 & 32.65 & 0.0814 & - & - & 0.0947 & 8.742 & 0.9880 & 0.9760 & 55 \\
\hline Model IV & 132.6 & 197.6 & 0.0014 & 251.3 & -0.0110 & - & 31.281 & 0.9572 & 0.8715 & 92 \\
\hline
\end{tabular}

${ }^{1} a=$ rapidly soluble fraction $(\%) ; b=$ slowly degradable fraction $(\%) ; c=$ degradation rate constant $(\% / \mathrm{h})$ of fraction ' $\mathrm{b}$ '; $L=$ lag time (h); $d=$ is the parameter pertaining to the variable fractional rate of degradation; $k=$ slope, or degradation rate coefficient $\left(\mathrm{h}^{-1}\right)$; ${ }^{2} \mathrm{SSE}=$ Sum of Squares Due to Error; R-Square= the square of the correlation between the response values and the predicted response values; Adj R-Square= Degrees of Freedom Adjusted R-Square; Iter = iteration number of MATLAB.

${ }^{3}$ Model I, First-order kinetics model without lag phase; Model II, First-order kinetics model with lag phase; Model III, Gompertz model; Model IV, Generalised Mitscherlich model.

\section{Effective degradability}

Table 3 shows the fish meal and cottonseed meal main effect means for effective degradability
(ED) at the five rates of passage considered $(0.02 / \mathrm{h}$ $0.03 / \mathrm{h}, 0.04 / \mathrm{h}, 0.05 / \mathrm{h}$ or $0.06 / \mathrm{h}$ ).

Table 3

Estimated effective degradability (ED) of dry matter and crude protein of fish meal and cottonseed meal using different mathematical models

\begin{tabular}{cccccccccccc}
\hline & \multicolumn{3}{c}{$\mathrm{DM}^{1}$} & \multicolumn{1}{c}{$\mathrm{CP}$} \\
\hline & $\mathrm{k}^{2}=0.02$ & $\mathrm{k}=0.03$ & $\mathrm{k}=0.04$ & $\mathrm{k}=0.05$ & $\mathrm{k}=0.06$ & $\mathrm{k}=0.02$ & $\mathrm{k}=0.03$ & $\mathrm{k}=0.04$ & $\mathrm{k}=0.05$ & $\mathrm{k}=0.06$ \\
\hline Fish meal & & & & & & & & & & \\
Model I & 23.72 & 21.86 & 20.37 & 19.14 & 18.11 & 26.16 & 24.02 & 22.31 & 20.91 & 19.74 \\
Model II & 23.86 & 22.06 & 20.60 & 19.40 & 18.40 & 26.66 & 24.69 & 23.11 & 21.82 & 20.74 \\
Model III & - & - & - & - & - & - & - & - & - & - \\
Model IV & - & - & - & - & - & - & - & - & - & - \\
Cottonseed meal & & & & & & & & & & \\
Model I & 37.98 & 33.65 & 30.73 & 28.61 & 27.01 & 39.77 & 35.49 & 32.44 & 30.15 & 28.38 \\
Model II & 40.95 & 37.25 & 34.75 & 32.94 & 31.57 & 42.48 & 38.89 & 36.32 & 34.40 & 32.90 \\
Model III & - & - & - & - & - & 34.83 & 32.48 & 30.51 & 28.85 & 27.42 \\
Model IV & - & - & - & - & - & - & - & - & - & - \\
\hline
\end{tabular}

${ }^{1} D M=$ effective ruminal degradability of dry matter; $C P=$ effective ruminal degradability of crude protein ${ }^{2} k=$ the rumen fractional passage rate

${ }^{3}$ Model I, First-order kinetics model without lag phase; Model II, First-order kinetics model with lag phase; Model III, Gompertz model; Model IV, Generalised Mitscherlich model. 


\section{Discussion}

\section{Statistical models output}

According to fitted model (model II), there was part of the hour lag time in degradability, it can be said that the degradability of fish meal and cottonseed meal takes some $\mathrm{h}$ to be started.

Comparison of different models for estimating ruminal $\mathrm{CP}$ degradation parameters of fish meal revealed that models I and II reported by Ørskov and McDonald (1979) reach convergence, while other models because of estimated negative values, they were not biologically acceptable. Despite that the I, II and III models were reached convergence for $\mathrm{CP}$ degradability of cottonseed meal, based on the coefficient of determination $\left(\mathrm{R}^{2}\right)$ and Adjusted $\left(\mathrm{R}^{2}\right)$ showed that models III was fitting the best model.

\section{Effective degradability}

The ED declined as passage rates increased, because if the passage rates increased the rumen microorganisms will not have enough time to effect on the feed. According to the results, model II showed a higher amount of DM and CP effective degradability in fish meal and cottonseed meal. The ruminal biodegradability of $\mathrm{CP}$ affects the efficiency of nitrogen use for microbial protein synthesis. Starch fermentation rates can also affect the rate of ammonia consumption by altering the energy supply for microbial growth.

\section{Conclusions}

It can be concluded that only models I and II can be used for estimating the degradability of DM of fish meal and cottonseed meal, but in cottonseed protein, in addition to these models, the III model showed the good behavior.

\section{Acknowledgement}

The authors wish to express their sincere gratitude to Mrs. Somayyeh Shabestani for her valuable support in the English edition. Authors are thankful to Dr. Saeid Agahian for his technical assistance in part of the MATLAB analysis

\section{Authors' contributions}

VP collected the data for this study, conducted the statistical analyses, VP and MB developed the original hypotheses and designed the experiments, VP collaborated in interpreting the results and finalized the manuscript. Both authors have read and approved the finalized manuscript

\section{Conflict of Interest Declaration}

The authors declare that they have no known competing financial interests or personal relationship that could have appeared to influence the work reported in this paper.

\section{References}

Bannink, A., van Lingen, H. J., Ellis, J. L., France, J., \& Dijkstra, J. (2016). The contribution of mathematical modeling to understanding dynamic aspects of rumen metabolism. Frontiers in Microbiology, 7, 1820. doi: 10.3389/ fmicb.2016.01820

Çavdar, T., Mohammad, M., \& Milani, R. A. (2013). A new heuristic approach for inverse kinematics of robot arms. Advanced Science Letters, 19(1), 329333. doi: 10.1166/asl.2013.4700

Chanzanagh, E. G., Seifdavati, J., Gheshlagh, F. M. A., Abdibenemar, H., \& Seyedsharifi, R. (2019). Comparison of two mathematical models to describe the rumen fermentation parameters of some sources of plant and animal protein using in vitro gas method. Asian Journal of Research in Animal and Veterinary Sciences, 3(1), 1-6. Recovered from http://www. sdiarticle3.com/review-history/47943

Dhanoa, M. S., France, J., Siddons, R. C., Lopez, S., \& Buchanan, S. J .G. (1995). A non-linear compartmental model to describe for age degradation kinetics during incubation in polyester bags in the 
rumen. British Journal of Nutrition, 73, 3-15. doi: 10.1079/BJN19950004

Dijkstra, J., Bannink, A., Bosma, P. M., Lantinga, E. A., \& Reijs, J. W. (2018). Modeling the effect of nutritional strategies for dairy cows on the composition of excreta nitrogen. Frontiers in Sustainable Food Systems, 2, 63. doi: 10.3389/fsufs.2018.00063

France, J., Thornley, J. H. M., Lopez, S., Siddons, R. C., Dhanoa, M. S., Van Soest, P. J., \& Gill, M. (1990). On the two-compartment model for estimating extent of feed degradation in the rumen. Journal of Theoretical Biology, 146, 269-287. doi: 10.1016/ S0022-5193(05)80139-0

Gregorini, P., Provenza, F. D., Villalba, J. J., Beukes, P. C., \& Forbes, M. J. (2018). Dynamics of forage ingestion, oral processing and digesta outflow from the rumen: a development in a mechanistic model of a grazing ruminant, MINDY. The Journal of Agricultural Science, 156(8), 980-995. doi: 10.1017/ S00 21859618000886

Hanigan, M. D., \& Daley, V. L. (2019). Use of mechanistic nutrition models to identify sustainable food animal production. Annual Review of Animal Biosciences, 8, 355-376. doi: 10.1146/annurev-animal-021 419083913

Jin, L., Dunière, L., Lynch, J. P., Zaheer, R., Turkington, K., Blackshaw, R. E., \& Baah, J. (2017). Impact of ferulic acid esterase producing lactobacilli and fibrolytic enzymes on ensiling and digestion kinetics of mixed small grain silage. Grass and Forage Science, 72(1), 80-92. doi: 10.1111/gfs. 12217

Lapierre, H., Larsen, M., Sauvant, D., Van Amburgh, M. E., \& Van Duinkerken, G. (2018). Converting nutritional knowledge into feeding practices: a case study comparing different protein feeding systems for dairy cows. Animal, 12(s2), s457-s466. doi: $10.1017 / \mathrm{S} 1751731118001763$

Lopes, F. C. F., Campos, M. M., Borges, A. L. D. C. C., Pancoti, C. G., Reis, R., \& Moreira, T. S. (2018). Rumen parameters and passage rate in cattle fed diets based on sugarcane hydrolyzed with calcium oxide. Semina: Ciências Agrárias, 39(6), 2783-2794. doi: 10.5433/1679-0359.2018v39n6p2783

Milani, M. M. R. A., Çavdar, T., \& Aghjehkand, V. F. (2012). Particle swarm optimization based determination of Ziegler-Nichols parameters for PID controller of brushless DC motors. International Symposium on Innovations in Intelligent Systems and Applications (pp. 1-5). IEEE. doi: 10.1109/ INISTA.2012.6246984

Oberson, J. L., Probst, S., \& Schlegel, P. (2019).
Magnesium absorption as influenced by the rumen passage kinetics in lactating dairy cows fed modified levels of fibre and protein. Animal, 13(7), 14121420. doi: $10.1017 / \mathrm{S} 1751731118002963$

Ørskov, E. R., Hovel, F. D. B., \& Mould, F. L. (1980). The use of the nylon bag technique for evaluation of feedstuffs. Tropical Animal Production, 5, 195-213. Recovered from http://www.fao.org/ WAICENT/ faoINFO/AGRICULT/AGA/AGAP/ FRG/TAP53/53_1.pdf

Ørskov, E. R. I., \& McDonald, I. M. (1979). The estimation of protein degradability in the rumen from incubation measurements weighted according to rate of passage. Journal of Agricultural Sciences, 92, 499-503. doi: 10.1017/S0021859600063048

Palangi, V., \& Macit, M. (2019). In situ crude protein and dry matter ruminal degradability of heat-treated barley. Revue de Medecine Veterinaire, 170(7-9), 123-128. Recovered from https://www.revmedvet. com/2019/RMV170_123_128.pdf

Reed, K. F., Arhonditsis, G. B., France, J., \& Kebreab, E. (2016). Bayesian calibration of dynamic ruminant nutrition models. Journal of Dairy Science, 99(8), 6362-6370. doi: 10.3168/jds.2015-10708

Rochen, N. M. R. Jr., Silva, M. C. da, Abreu, M. L. C., Oliveira, J. G. de, Glória, L. S., Tedeschi, L. O., \& Vieira, R. A. M. (2020). The transit of external markers throughout the ruminant digestive tract: 1. The fitting quality of models to marker profiles in feces using an information-theoretic approach. Animal Feed Science and Technology, 261, 114407. doi: 10.1016/j.anifeedsci.2020.114407

Sauvant, D., \& Noziere, P. (2016). Quantification of the main digestive processes in ruminants: the equations involved in the renewed energy and protein feed evaluation systems. Animal, 10(5), 755-770. doi: 10. 1017/S1751731115002670

Vaga, M., \& Huhtanen, P. (2018). In vitro investigation of the ruminal digestion kinetics of different nitrogen fractions of $15 n$-labelled timothy forage. Plos One, 13(9), e0203385. doi: 10.1371/journal. pone. 0203385

Van Soest, P. J. (2018). Nutritional ecology of the ruminant. Cornell University Press.

Yousefian, S., Teimouri Yansari, A., \& Chashnidel, Y. (2019). The effects of Indigestible Neutral Detergent Fiber (iNDF) of alfalfa hay and corn silage on ruminal degradability of ration fiber in sheep. Iranian Journal of Applied Animal Science, 9(1), 73-78. Recovered from http://www.iaujournals.ir/ article $663556 . \mathrm{html}$ 